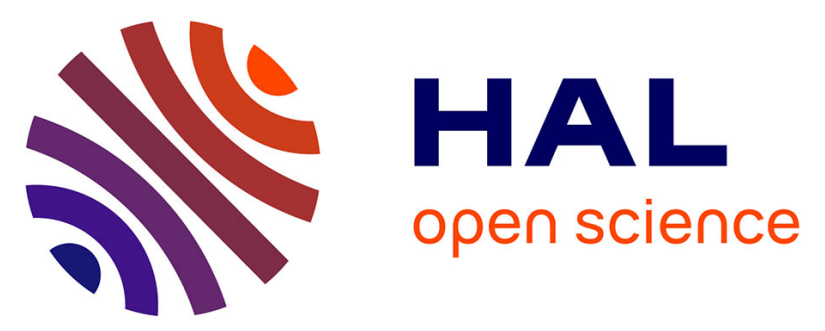

\title{
Biochemical Characterization and Immunocytochemical Localization of EM66, a Novel Peptide Derived from Secretogranin II, in the Rat Pituitary and Adrenal Glands
}

Maite Montero-Hadjadje, Georges Pelletier, Laurent Yon, Songyun Li, Johann

Guillemot, Rabia Magoul, Yves Tillet, Hubert Vaudry, Youssef Anouar

\section{To cite this version:}

Maite Montero-Hadjadje, Georges Pelletier, Laurent Yon, Songyun Li, Johann Guillemot, et al.. Biochemical Characterization and Immunocytochemical Localization of EM66, a Novel Peptide Derived from Secretogranin II, in the Rat Pituitary and Adrenal Glands. Journal of Histochemistry and Cytochemistry, 2003, 51 (8), pp.1083 - 1095. 10.1177/002215540305100812 . hal-01706425

\section{HAL Id: hal-01706425}

https://hal-normandie-univ.archives-ouvertes.fr/hal-01706425

Submitted on 19 Jul 2018

HAL is a multi-disciplinary open access archive for the deposit and dissemination of scientific research documents, whether they are published or not. The documents may come from teaching and research institutions in France or abroad, or from public or private research centers.
L'archive ouverte pluridisciplinaire HAL, est destinée au dépôt et à la diffusion de documents scientifiques de niveau recherche, publiés ou non, émanant des établissements d'enseignement et de recherche français ou étrangers, des laboratoires publics ou privés. 


\title{
Biochemical Characterization and Immunocytochemical Localization of EM66, a Novel Peptide Derived from Secretogranin II, in the Rat Pituitary and Adrenal Glands
}

\author{
Maité Montero-Hadjadje, Georges Pelletier, Laurent Yon, Songyun Li, Johann Guillemot, \\ Rabia Magoul, Yves Tillet, Hubert Vaudry, and Youssef Anouar
}

European Institute for Peptide Research (IFRMP 23), Laboratory of Cellular and Molecular Neuroendocrinology, INSERM U413, UA CNRS, University of Rouen, Mont-Saint-Aignan, France (MM-H,LY,JG,HV,YA); Laboratory of Molecular Endocrinology, Laval University Medical Center, Quebec, Canada (GP,SL); Laboratory of Animal Physiology, University Sidi Mohamed Ben Abdellah, Fes-Atlas, Morocco (RM); and Laboratory of Neuroendocrinology, INRA-CNRS, Nouzilly, France (YT)

\begin{abstract}
SUMMARY Characterization of secretogranin II (Sgll) mRNA in various vertebrates has revealed selective conservation of the amino acid sequences of two regions of the protein, i.e., the bioactive peptide secretoneurin and a flanking novel peptide that we named EM66. To help elucidate the possible role of EM66, we examined the occurrence as well as the cellular and subcellular distribution of EM66 in rat pituitary and adrenal glands by using a polyclonal antibody raised against the recombinant human EM66 peptide. High-performance liquid chromatography (HPLC) analysis of rat pituitary and adrenal extracts combined with a radioimmunoassay resolved EM66-immunoreactive material exhibiting the same retention time as recombinant EM66. In the rat pituitary, double-labeling immunohistochemical (IHC) studies showed that EM66 immunoreactivity (IR) was present in gonadotrophs, lactotrophs, thyrotrophs, and melanotrophs, whereas corticotrophs were devoid of labeling. EM66-IR was also observed in nerve endings in the neural lobe. Immunocytochemical staining at the electron microscopic level revealed that EM66-IR is sequestered in the secretory granules within gonadotrophs and lactotrophs. In the adrenal medulla, double IHC labeling showed that EM66-IR occurs exclusively in epinephrine-synthesizing cells. At the ultrastructural level, EM66-IR was seen in chromaffin vesicles of adrenomedullary cells. These results demonstrate that post-translational processing of Sgll generates a novel peptide that exhibits a cell-specific distribution in the rat pituitary and adrenal glands where it is stored in secretory granules, supporting the notion that EM66 may play a role in the endocrine system. (J Histochem Cytochem 51:1083-1095, 2003)
\end{abstract}

\author{
KEY WORDS \\ secretogranin II \\ chromogranins \\ novel peptides \\ EM66 \\ pituitary cells \\ adrenal medulla \\ immunohistochemistry \\ electron microscopy \\ HPLC analysis
}

SeCRETOGRAnin II (SgII) belongs to the chromogranin/secretogranin protein family whose members occur in most endocrine, neuroendocrine, and nerve cells (Rosa and Gerdes 1994; Fischer-Colbrie et al. 1995). These acidic secretory proteins play a role in the morphogenesis of secretory vesicles (Iacangelo and Eiden 1995; Kim et al. 2001). There is also evidence that granins are precursor proteins that can be processed

Correspondence to: H. Vaudry, European Institute for Peptide Research (IFRMP23), Lab. of Cellular and Molecular Neuroendocrinology, INSERM U413, UA CNRS, University of Rouen, 76821 Mont-Saint-Aignan, France. E-mail: hubert.vaudry@univ-rouen.fr

Received for publication October 1, 2002; accepted February 26, 2003 (2A5926). by prohormone convertases (PCs) to generate bioactive peptides (Simon and Aunis 1989; Winkler and Fischer-Colbrie 1992; Iacangelo and Eiden 1995). In particular, SgII is the precursor of a peptide named secretoneurin (SN) (Vaudry and Conlon 1991; Kirchmair et al. 1993) which has been implicated in the modulation of the inflammatory response and may represent a novel sensory peptide for neuroimmunomodulation (Wiedermann 2000). The cloning of the cDNAs encoding various members of the chromogranin/secretogranin family in species that are phylogenetically distant from mammals, has revealed the existence within these proteins of a few domains that have been remarkably conserved during evolution, whereas the remaining sequences profoundly diverged 
among species (Anouar et al. 1996; Holthuis and Martens 1996; Blazquez et al. 1998; Turquier et al. 1999; Ait-Ali et al. 2002). Moreover, the sequences of the conserved regions are delimited by preserved dibasic amino acids which represent potential cleavage sites for PCs (Laslop et al. 2000; Turquier et al. 2000). For example, although SgII displays only $46 \%$ overall amino acid sequence identity between frog and human, high sequence homology occurs in the regions encoding SN and its C-terminal flanking peptide, and the two sequences are bounded by paired basic residues (Figure 1) (Anouar et al. 1996; Holthuis and Martens 1996; Blazquez et al. 1998). This observation suggests that the 66-amino-acid peptide flanking SN may also give rise to a mature peptide in endocrine, neuroendocrine, and neuronal cells that could play regulatory functions. This peptide was named EM66 in consideration of its $\mathrm{N}$ - and C-terminal glutamic acid and methionine residues, respectively, in the human sequence. We have raised polyclonal antibodies against a fusion protein encompassing the human EM66 sequence that was produced in Escherichia coli. Using these antibodies, we have shown that EM66 is actually generated in the adult and fetal human adrenal gland, thus establishing the existence of this novel SgII-derived peptide (Anouar et al. 1998).

As a further step towards the elucidation of the possible role of EM66, the aim of the present study was to investigate the occurrence of EM66 in the rat pituitary and adrenal glands, where high amounts of the precursor protein SgII and its processing products are found (Anouar and Duval 1991; Lloyd et al. 1992; Fischer-Colbrie et al. 1995; Leitner et al. 1996), and to determinate the precise cellular and subcellular localization of EM66 within these tissues.

\section{Materials and Methods}

\section{Animals and Tissue Samples}

Three-month-old male Wistar rats weighing 250 to $300 \mathrm{~g}$ were maintained under controlled conditions of temperature

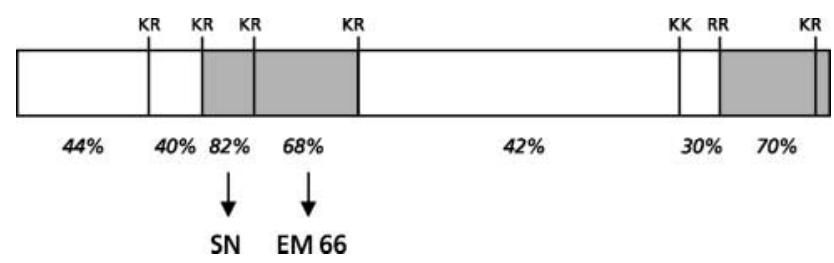

Figure 1 Schematic representation of the structure of Sgll showing the location of conserved regions (shaded zones) between the frog and human Sgll sequences. Two of these domains correspond to SN and EM66. The conserved dibasic sites and the percentages of amino acid identity between frog and human sequences are indicated.
(22C) and an established photoperiod (lights on from 0700 hr to $1900 \mathrm{hr}$ ). Rats had free access to laboratory chow (UAR; Epinay-sur-Orge, France) and water. All manipulations were performed according to the recommendations of the French Ethical Committee and under the supervision of authorized investigators. The animals were sacrificed by decapitation between $0830 \mathrm{hr}$ and $0930 \mathrm{hr}$, and the adrenal glands and pituitaries were quickly removed and frozen at $-80 \mathrm{C}$.

\section{Production of Recombinant EM66}

A fusion protein containing the human EM66 peptide was produced in E. coli as previously described (Anouar et al. 1998). Briefly, the cDNA sequence encoding the EM66 region in human SgII was amplified by PCR, inserted downstream of the maltose-binding protein (MBP) region of the plasmid pMAL-c2 (New England Biolabs; Beverly, MA), and expressed in bacteria. The cleavage of the affinity-purified fusion protein with factor Xa releases EM66 with the native amino acid sequence.

\section{Antibodies}

Antibodies against EM66 (code 736-1806) were raised in rabbits against the recombinant fusion protein MBP-EM66, and their specificity has been established by Western blotting and IHC (Anouar et al. 1998). A mouse monoclonal antibody (code 518 B7) against the luteinizing hormone $\beta$-subunit $(\mathrm{LH} \beta)$ was a generous gift from Dr J.F. Roser (Matteri et al. 1987). The adrenocorticotropin (ACTH) antibody (code 105-10) was raised against ACTH 1-24 in sheep and was provided by Dr J. Cote (Jegou et al. 1983). The development of the rabbit antibodies against rat prolactin (PRL) (code 19602), bovine phenylethanolamine $N$-methyltransferase (PNMT) (code 19886) and human thyroid-stimulating hormone $\beta$-subunit (TSH $\beta$ ) has been previously described (Martinat et al. 1979; Tillet 1988; Uchiyama et al. 2000). The mouse monoclonal antibody directed against tyrosine hydroxylase $(\mathrm{TH})$ was purchased from Chemicon International (Temecula, CA). Fluorescein isothiocyanate (FITC)-conjugated goat anti-mouse (GAM/FITC), FITC-conjugated donkey anti-sheep (DAS/FITC), FITC-conjugated goat anti-rabbit (GAR/FITC), and Texas Red-conjugated donkey anti-rabbit (DAR/TXR) $\gamma$-globulins were from Amersham International (Poole, UK).

\section{Immunohistochemical Procedure}

For light microscopic IHC the rat adrenal and pituitary glands were dipped overnight in Stefanini's fixative consisting of $4 \%$ paraformaldehyde, $0.2 \%$ picric acid in $0.1 \mathrm{M}$ phosphate buffer (PB), pH 7.4, rinsed with $\mathrm{PB}$, and frozen at $-80 \mathrm{C}$ in Tissue-Tek (Leica; Nussloch, Germany). Frozen glands were sliced into $10-\mu \mathrm{m}$ sections using a cryomicrotome (Frigocut; Reicher-Jung, Nussloch, Germany). After several rinses in $\mathrm{PB}$, tissue sections were processed for indirect immunofluorescence microscopy. Slices were incubated overnight at $4 \mathrm{C}$ with one or two (in the case of double labeling) primary antibodies, i.e., the EM66 antiserum diluted 1:500, the TH antibody diluted 1:400, the LH $\beta$ antibody diluted 1:300, the ACTH antiserum diluted 1:500, the PRL antiserum diluted 1:2000, the TSH $\beta$ antiserum diluted 
1:100, or the PNMT antiserum diluted 1:500 in PB containing $0.3 \%$ Triton $\mathrm{X}-100$ and $1 \%$ bovine serum albumin (BSA; Roche Diagnostics, Mannheim, Germany). Tissue sections were rinsed in PB for $30 \mathrm{~min}$ and incubated for $90 \mathrm{~min}$ at room temperature (RT) with the appropriate secondary antibody, i.e., GAR/FITC, DAS/FITC, GAM/FITC diluted 1:100, or DAR/TXR diluted 1:50. Finally, slices were rinsed and mounted with PB/glycerol (1:1), coverslipped, and examined using a confocal laser scanning microscope (CLSM; Leica, Heidelberg, Germany) equipped with a diaplan optical system and an argon/krypton ion laser (excitation wavelengths $488 / 568 / 647 \mathrm{~nm}$ ). To verify the specificity of the immunoreaction, various controls were performed: (a) substitution of the primary antisera/antibodies with PB; (b) incubation with non-immune serum instead of the primary antisera; (c) liquid-phase preabsorption of the EM66 antiserum (diluted 1:500) with purified recombinant peptide $\left(10^{-6} \mathrm{M}\right)$.

\section{Immunoelectron Microscopy}

Three-month-old adult male Sprague-Dawley rats (225-250 g) were perfused transcardially with $200 \mathrm{ml}$ of $2.5 \%$ glutaraldehyde in 0.1 M PB. Pituitaries and adrenal glands were excised and postfixed in the same fixative for $6 \mathrm{hr}$ at 4C. Then the anterior lobes of the pituitaries and the adrenals were cut into small fragments $\left(\sim 1 \mathrm{~mm}^{3}\right)$. The tissues were rinsed overnight in the same buffer and postfixed for $1 \mathrm{hr}$ in $0.2 \% \mathrm{OsO}_{4}$. After rinsing for $2 \mathrm{hr}$ in distilled water, the tissues were dehydrated in ethanol and embedded in Araldite. Semithin sections were first performed for selection of the areas of interest in each gland. Ultrathin sections from the anterior lobe of the pituitary, and medullary and cortical zones of the adrenal gland, were then cut with a diamond knife and collected on nickel grids. Tissue sections were immunostained using the protein A-gold complex (10 nm; British Biocell, Cardiff, UK), as described (Roth et al. 1978). The EM66 antiserum was used at a 1:200 dilution. Control experiments were performed by substituting non-immunized rabbit serum (1:200) or the antiserum (1:200) preabsorbed with an excess of antigen $\left(10^{-6} \mathrm{M}\right)$. After the immunostaining procedures, the sections were counterstained with $1 \%$ uranyl acetate and lead citrate.

\section{Tissue Extraction}

Frozen rat pituitary and adrenal glands were immersed for $10 \mathrm{~min}$ in a cooled solution of $75 \%$ ethanol $/ 18 \%$ hydrochloric acid $(10 \mathrm{~N})$. The tissue samples were sonicated and centrifuged at $10,000 \times \mathrm{g}$ for $30 \mathrm{~min}$ at $4 \mathrm{C}$. The supernatants were collected and dried by vacuum centrifugation (SpeedVac Concentrator; Savant AES 2000, Hicksville, NY). The samples were reconstituted in $0.1 \%$ TFA in water and loaded onto three Sep-Pak $\mathrm{C}_{18}$ cartridges (Waters Associates; Milford, MA) connected in series. The bound material was eluted with a solution of acetonitrile/water/TFA (49.9:50:0.1, v/v/v). The solvent was evaporated in the Speed-Vac Concentrator and the samples were kept dry until chromatographic analysis.

\section{High-performance Liquid Chromatography (HPLC) Analysis}

Dried samples were reconstituted in $1 \mathrm{ml}$ of $0.1 \%$ TFA and centrifuged at $10,000 \times \mathrm{g}$ for $10 \mathrm{~min}$ at $4 \mathrm{C}$. The superna-
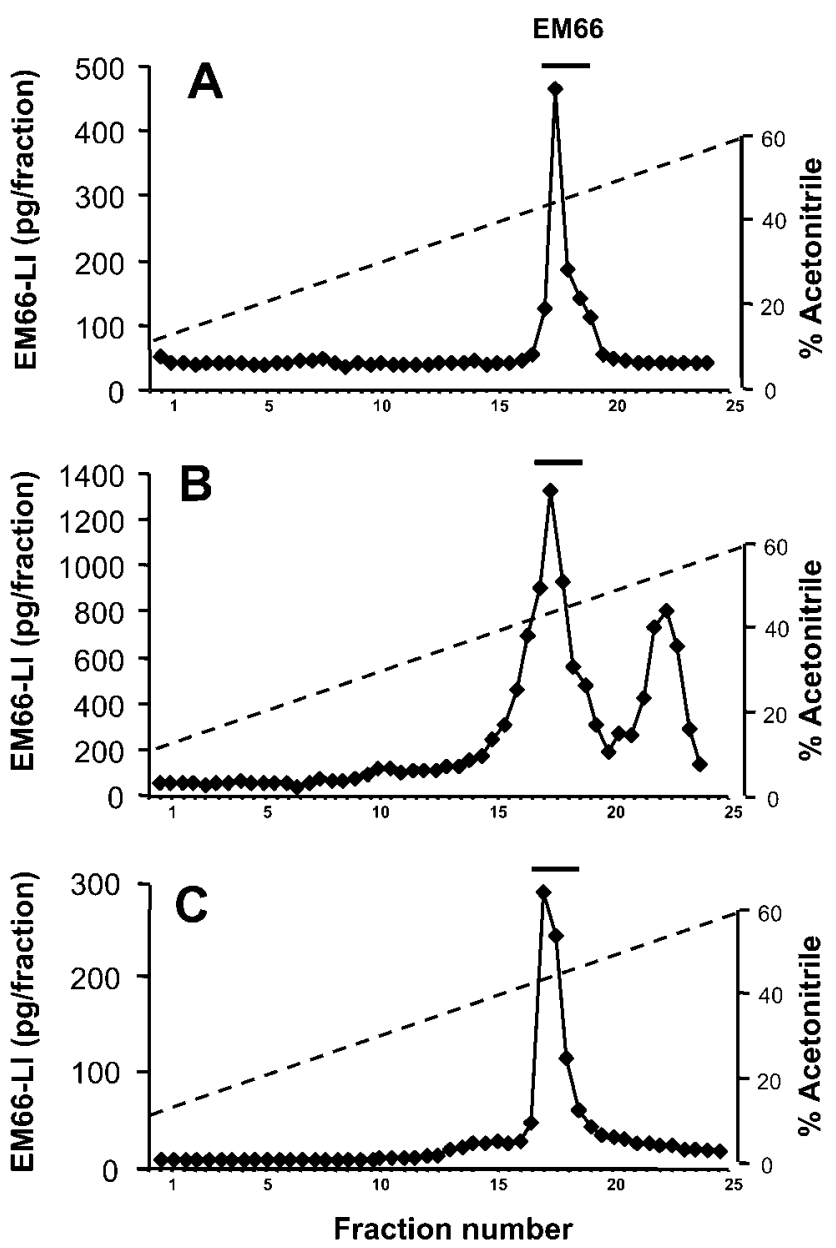

Figure 2 RP-HPLC analysis of EM66-like immunoreactivity (LI) in the rat pituitary and adrenal glands. (A) Elution profile of recombinant EM66 chromatographed onto a Vydac $\mathrm{C}_{18}$ column. Fractions of $1 \mathrm{ml}$ were collected, dried, and radioimmunoassayed for EM66. Protein extracts prepared from 50 pituitary anterior lobes (B) and from 30 adrenal glands (C) were pre-purified on Sep-Pak cartridges, analyzed as described above, and radioimmunoassayed for EM66. The bars above the peaks indicate the elution position of recombinant EM66, as indicated in $\mathbf{A}$.

tants were injected onto a $0.45 \times 25-\mathrm{cm}$ Vydac $\mathrm{C}_{18}$ column equilibrated with a solution of acetonitrile/water/TFA (9.9:90:0.1, v/v/v) at a flow rate of $1 \mathrm{ml} / \mathrm{min}$. The concentration of acetonitrile in the eluting solvent was raised to $60 \%$ over 25 min using a linear gradient. HPLC standard consisted of $1 \mu \mathrm{g}$ purified recombinant EM66. Fractions of $1 \mathrm{ml}$ were collected, evaporated, and kept dry until RIA.

\section{Radioimmunoassay}

The concentrations of EM66-like material in the rat tissues were measured by RIA. Purified recombinant EM66 was iodinated by the chloramine- $\mathrm{T}$ method and separated from free iodine on Sep-Pak $\mathrm{C}_{18}$ cartridges using a gradient of acetonitrile $(0-100 \%)$ in $0.1 \%$ TFA. Radioiodinated EM66 eluted at $32 \%$ acetonitrile. The RIA was performed 
in $20 \mathrm{mM}$ veronal buffer, $\mathrm{pH} 9.1$, containing $3 \%$ BSA. The EM66 antiserum, used at a final dilution of 1:60,000, was incubated with $7000 \mathrm{cpm}$ of tracer/tube in the presence of recombinant EM66 (standard peptide) or HPLC fractions. After a 2-day incubation at 4C, the antibody-bound fraction was immunoprecipitated by addition of $200 \mu \mathrm{l}$ goat anti-rabbit $\gamma$-globulins (1:30), $200 \mu \mathrm{l}$ normal rabbit serum $(1: 150)$, and $500 \mu \mathrm{l}$ of $5 \%$ polyethyleneglycol 8000 . After a 2 -hr incubation at RT, the mixture was centrifuged $(5000 \times$ $\mathrm{g}, 4 \mathrm{C}, 30 \mathrm{~min}$ ), and the pellet containing the bound fraction was counted on a $\gamma$-counter (LKB; Wallack, Rockville, $\mathrm{MD})$.

\section{Results}

Characterization of EM66-IR in Pituitary and Adrenal Gland Extracts

Reversed-phase (RP)-HPLC analysis combined with RIA detection was conducted to characterize EM66 in rat pituitary and adrenal extracts (Figure 2). Recombi- nant EM66 eluted as a single peak with a retention time of $17.5 \mathrm{~min}$ (Figure 2A). A major EM66-IR peak exhibiting the same retention time as the recombinant peptide was detected in the adenohypophysial (Figure 2B) and adrenal (Figure 2C) gland extracts. A more hydrophobic EM66-immunoreactive compound eluting at 22.5 min was also resolved in the adenohypophysial gland extract (Figure 2B).

\section{Distribution of EM66-IR in the Pituitary}

The EM66 antiserum strongly labeled many cells in the anterior lobe (Figures 3A and 3C) and moderately stained most melanotrophs in the intermediate lobe of the rat pituitary (Figures $3 \mathrm{C}$ and $3 \mathrm{D})$. At a higher magnification, EM66-IR was also observed in nerve endings in the neural lobe (Figure 3D). No staining was seen when the EM66 antiserum was preabsorbed with $10^{-6} \mathrm{M}$ of the recombinant peptide and when
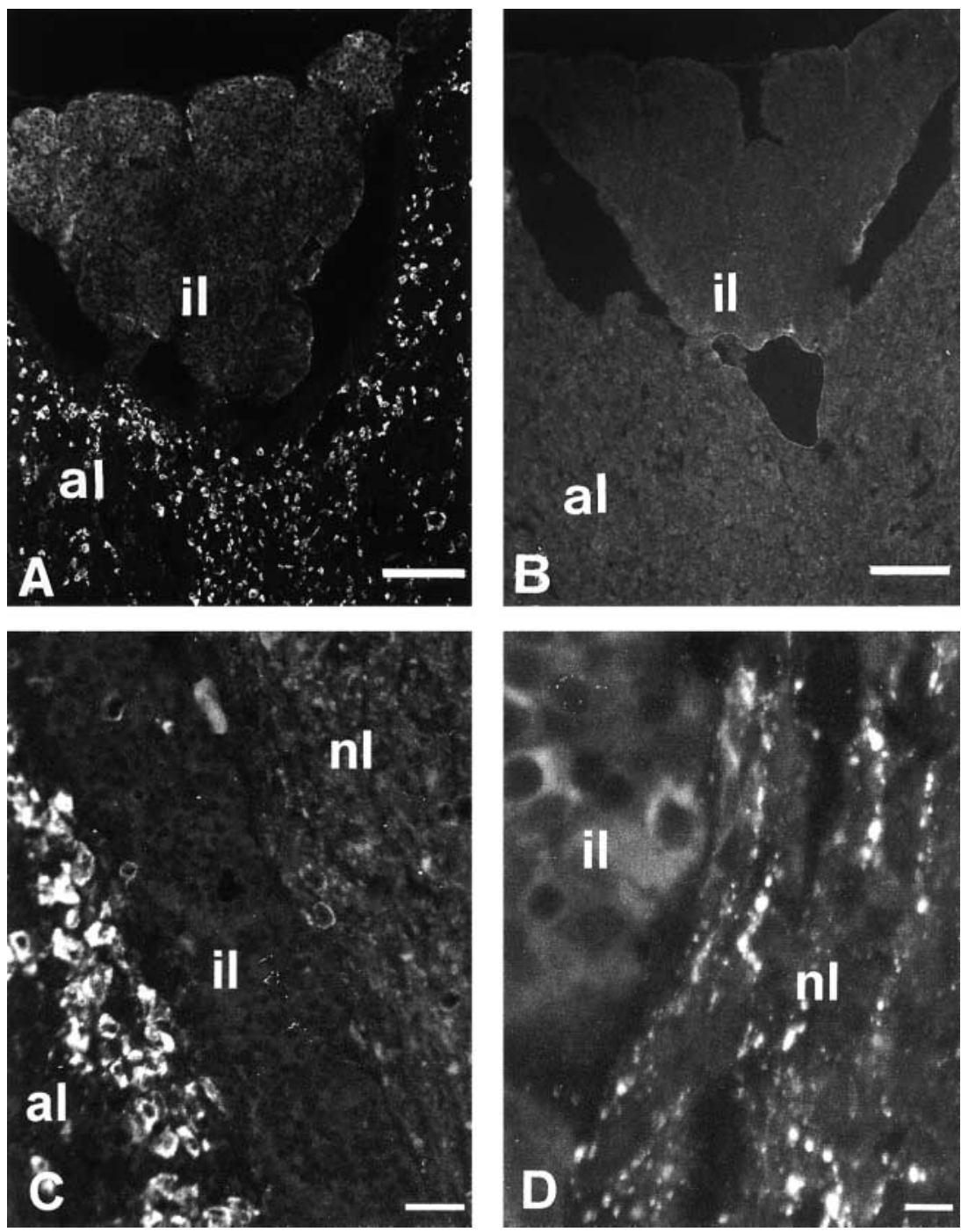

Figure 3 Photomicrographs showing the distribution of EM66-like immunoreactivity in the rat pituitary. Consecutive sections of a rat pituitary gland were incubated with the EM66 antiserum (A) or with the same antiserum preabsorbed overnight with $10^{-6} \mathrm{M}$ purified EM66 (B). (C) Intense immunofluorescence labeling was observed in many cells of the anterior lobe (al) and moderate labeling of melanotrophs in the intermediate lobe (il) as well as nerve fibers in the neural lobe ( $\mathrm{nl}$ ). (D) Higher magnification showing the distribution of EM66-like immunoreactivity in the intermediate and neural lobes. Bars: $\mathbf{A}, \mathbf{B}=$ $150 \mu \mathrm{m} ; \mathrm{C}=50 \mu \mathrm{m} ; \mathbf{D}=10 \mu \mathrm{m}$. 

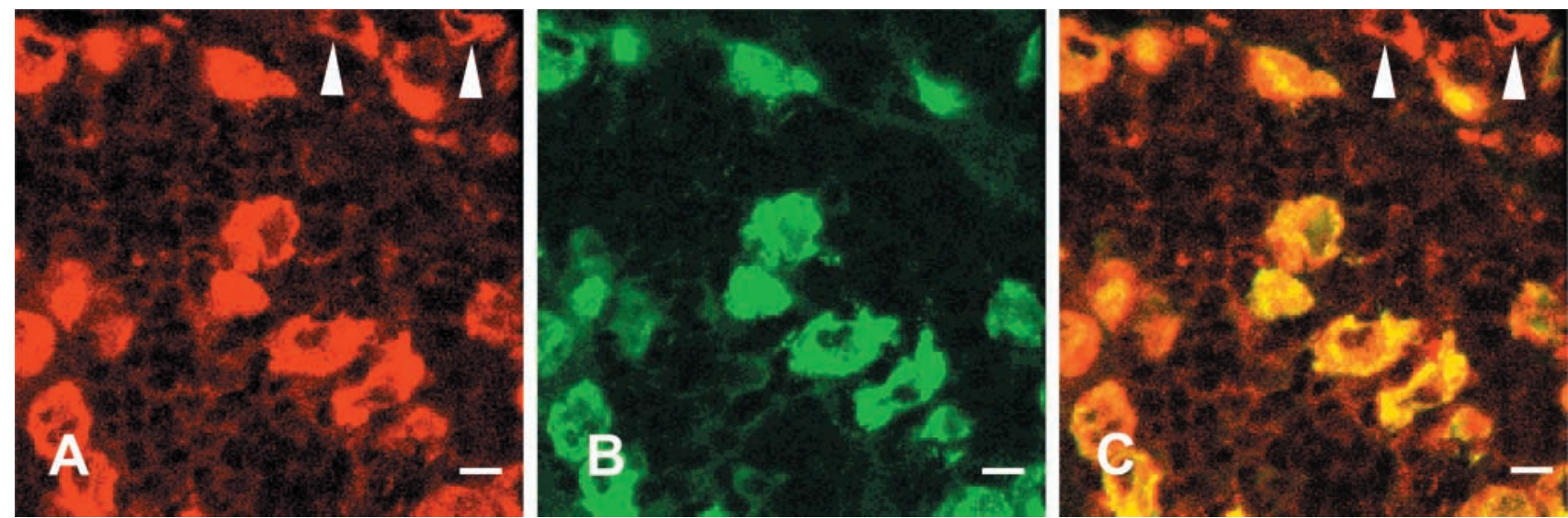

Figure 4 Confocal laser scanning microscope photomicrographs comparing the distribution of EM66 and LH $\beta$ immunoreactivity in the rat pituitary. Sections through the anterior lobe were labeled with a rabbit antiserum against EM66 (A) revealed with DAR/TXR and with a monoclonal antibody against the LH $\beta$ subunit (B) revealed with GAM/FITC. Combination of the two images acquired in $\mathbf{A}$ and $\mathbf{B}$ showed the presence of EM66-like immunoreactivity in all gonadotrophs (C). A few cells that were stained by the EM66 antibody were not immunoreactive to $\mathrm{LH} \beta$ (arrowheads). Bars $=10 \mu \mathrm{m}$.

the primary antibody was substituted with non-immune rabbit serum or $\mathrm{PB}$, thus confirming the specificity of the immunoreaction (Figure 3B).

Co-incubation of pituitary sections with the antiEM66 antiserum and the anti-LH $\beta$ antibody revealed that virtually all gonadotrophs contain EM66-IR (Figures 4A-4C). However, some EM66-IR cells did not exhibit any LH $\beta$-IR (Figures 4A-4C), indicating that the peptide occurs in cells other than gonadotrophs. Incubation of consecutive sections of the adenohypophysis with the anti-EM66 (Figure 5A) and anti-PRL (Figure 5B) antisera showed that some EM66-IR cells were lactotrophs (Figures 5A and 5B). Similarly, incubation of consecutive sections with the anti-EM66 (Figure 6A) and the anti-TSH $\beta$ (Figure 6B) antibodies revealed that EM66-IR is present in thyrotrophs (Figures 6A and 6B). On the contrary, corticotrophs that were immunostained with the ACTH antibodies (Figure 7B) were totally devoid of EM66-IR (Figures 7A-7C).

The different types of pituitary cells can readily be identified on the basis of their ultrastructural characteristics (Kurosumi 1968; Pelletier 1984). Somatotrophs are characterized by the presence of a large number of round or slightly ovoid secretory granules with a diameter of about 300-400 nm. Lactotrophs contain the largest granules of any pituitary cell. The mature secretory granules are often ovoid or elliptical, with a diameter ranging from 600 to $900 \mathrm{~nm}$. Gonadotrophs are characterized by the presence of two types of gran-
Figure 5 Photomicrographs showing the distribution of EM66- and PRLlike immunoreactivity in the rat pituitary. Consecutive sections through the anterior lobe of the pituitary were immunostained with antisera against EM66 (A) and PRL (B). Several lactotrophs were immunoreactive to EM66 (arrowheads). Bars $=20 \mu \mathrm{m}$.
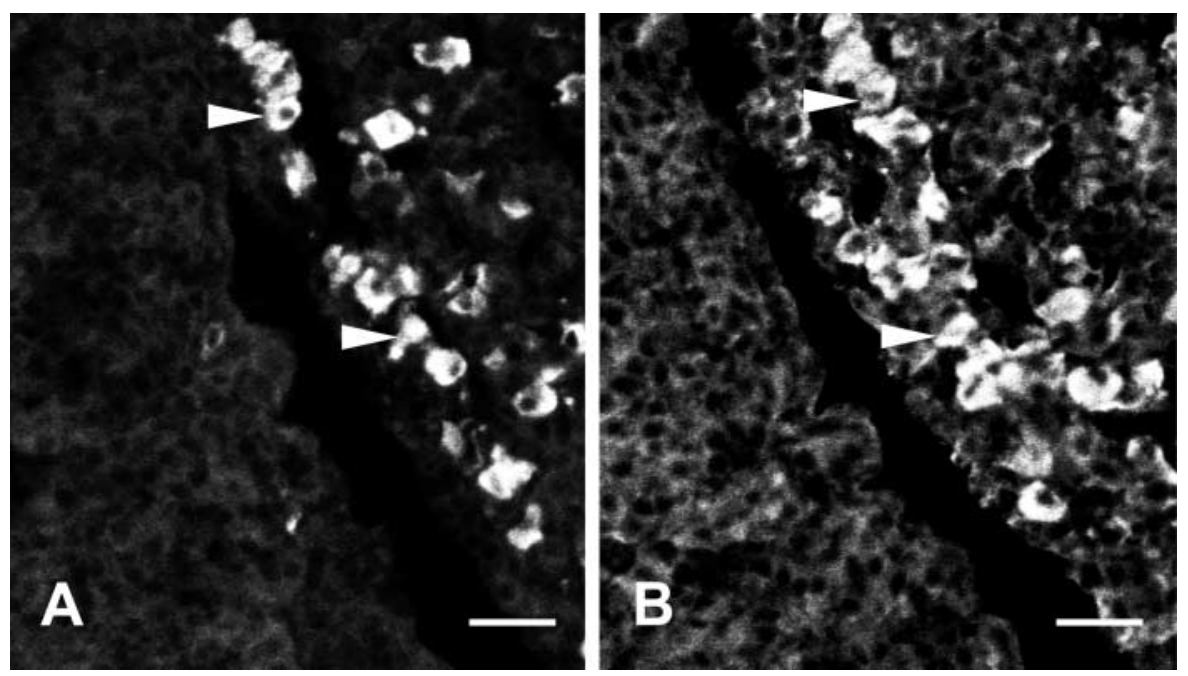

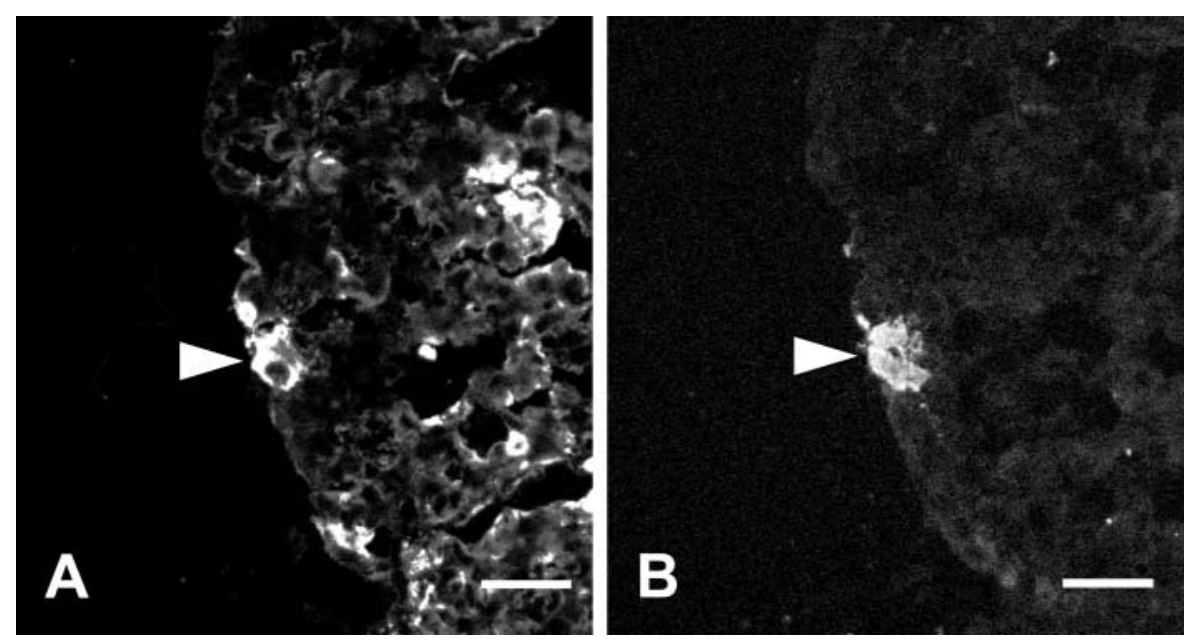

Figure 6 Immunofluorescence labeling of EM66 and TSH in the rat pituitary. Consecutive sections through the anterior lobe of the pituitary were immunostained with antisera against EM66 (A) and TSH $\beta$ (B). A thyrotroph that was stained by the EM66 antibody is indicated by an arrowhead. Bars $=20 \mu \mathrm{m}$. ules: the small (200 $\mathrm{nm}$ in diameter) and the large ones (350-700 $\mathrm{nm}$ in diameter). Corticotrophs can be identified by the presence of a single row of secretory granules (200 $\mathrm{nm}$ in diameter) exclusively located along the plasma membrane. Thyrotrophs have the smallest secretory granules (about $140 \mathrm{~nm}$ in diameter) of any cell type. EM66-IR material was only observed in secretory granules in gonadotrophs and lactotrophs. In gonadotrophs, both large and small secretory granules were decorated with gold particles (Figure 8A). The labeling of secretory granules of lactotrophs was generally weaker than that observed in gonadotrophs (Figure 8B). No labeling was observed in secretory granules of somatotrophs (Figure 8A). When the antiserum was absorbed with the antigen, no association of gold particles with any cell types in the anterior pituitary could be observed (data not shown).

\section{Distribution of EM66-IR in the Adrenal Gland}

The EM66 antibody strongly labeled the whole medulla (Figure 9A) and groups of cells located in the cortex (Figures 9A and 9B) of the rat adrenal gland. Preabsorption of the primary antiserum with $10^{-6} \mathrm{M}$ EM66 totally abolished the labeling (data not shown). Co-incubation of adrenal sections with the anti-EM66 and anti-TH antibodies revealed that virtually all adrenomedullary cells that were immunolabeled with the EM66 antiserum were also stained with the TH antibodies (Figures 10A-10C), indicating that EM66 is present in chromaffin cells. However, a few THpositive cells were devoid of EM66-IR (Figure 10C). Double immunolabeling of adrenal slices with the anti-PNMT and anti-TH antibodies (Figures 10D-10F) revealed that the EM66-negative chromaffin cells were also PNMT-negative (Figures 10C and 10F), indicat-
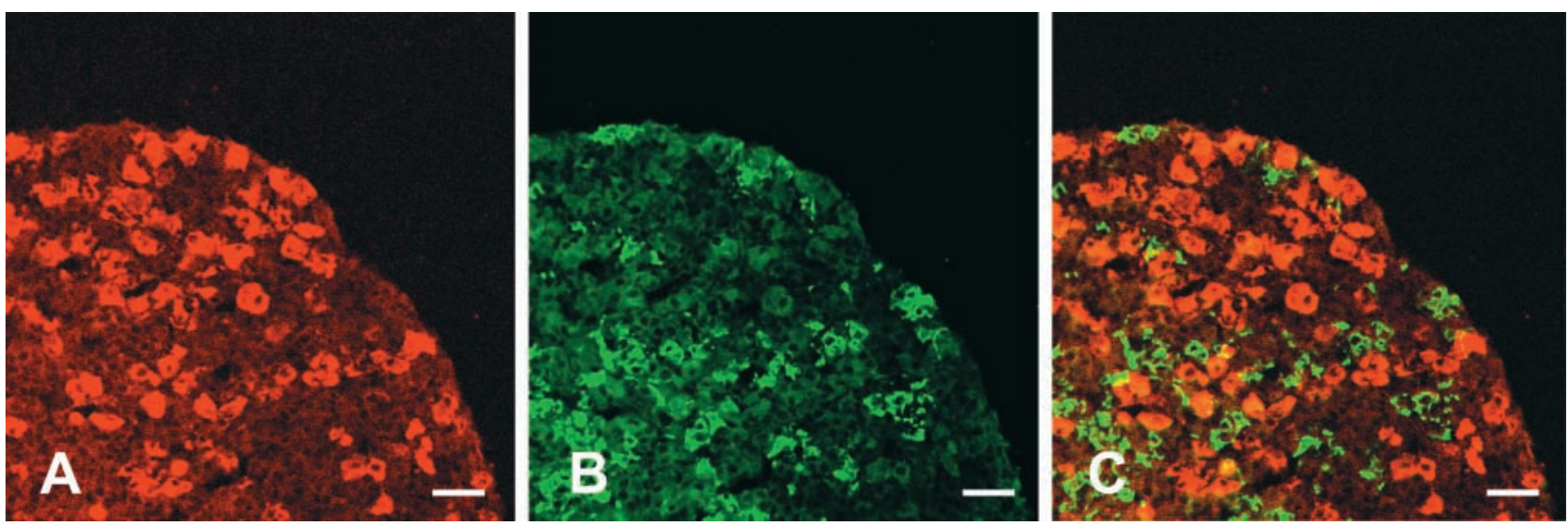

Figure 7 Confocal laser scanning microscope photomicrographs comparing the distribution of EM66 and ACTH-IR in the rat pituitary. Sections through the anterior lobe were labeled with a rabbit antiserum against EM66 (A) revealed with DAR/TXR and with a sheep antiserum against ACTH (B) revealed with DAS/FITC. Combination of the two images acquired in A and B showed the absence of EM66-like immunoreactivity in corticotrophs (C). Bars $=40 \mu \mathrm{m}$. 


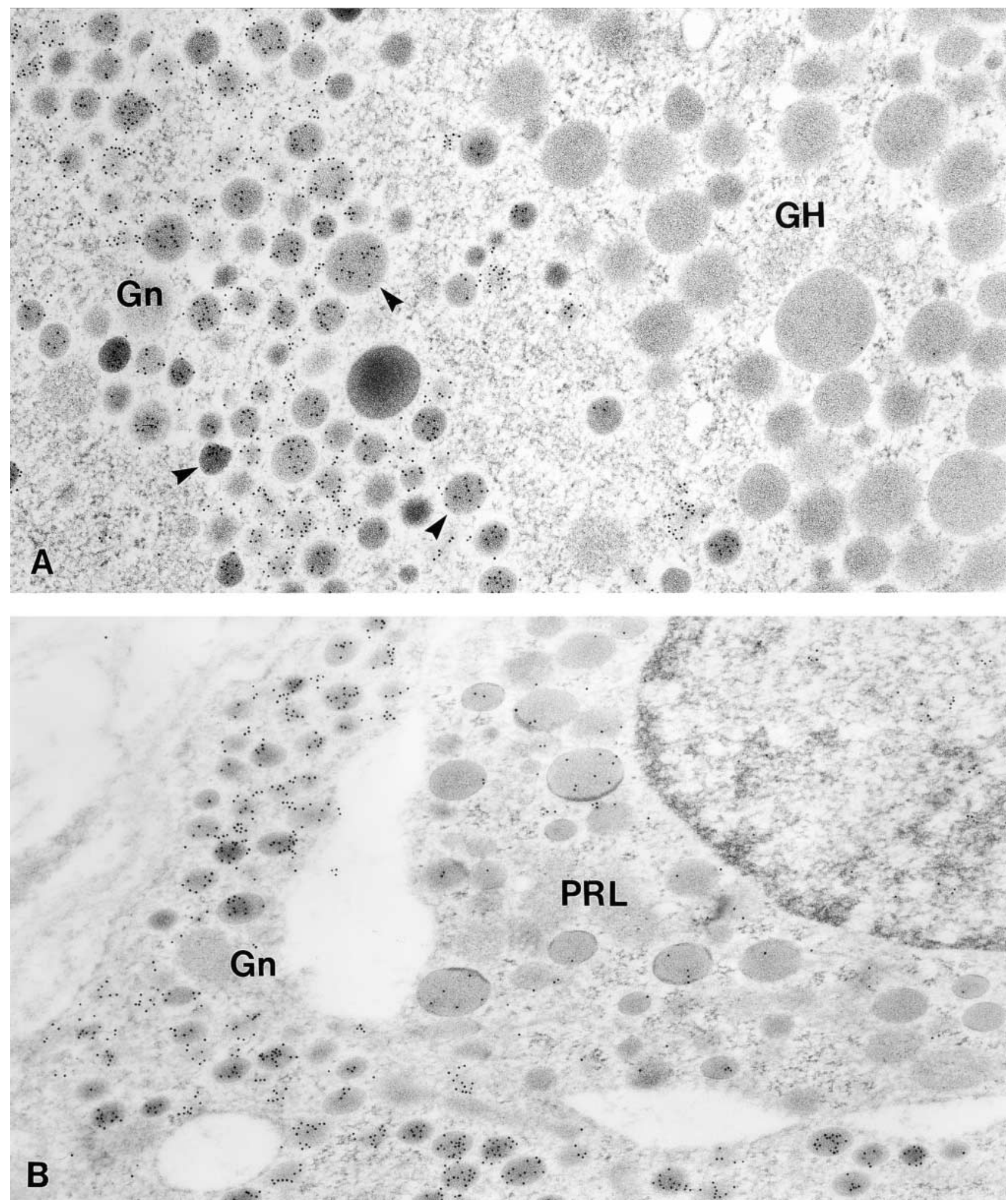

Figure 8 Immunoelectron microscopic localization of EM66 in the anterior pituitary gland. (A) Gold particles are located over the small and large secretory granules (arrowheads) of a gonadotroph (Gn). An adjacent somatotroph (GH) is unlabeled. (B) A few gold particles is also observed over the secretory granules of a prolactin cell (PRL). An adjacent gonadotroph (Gn) is more strongly labeled. Original magnification $\times 50,000$. 

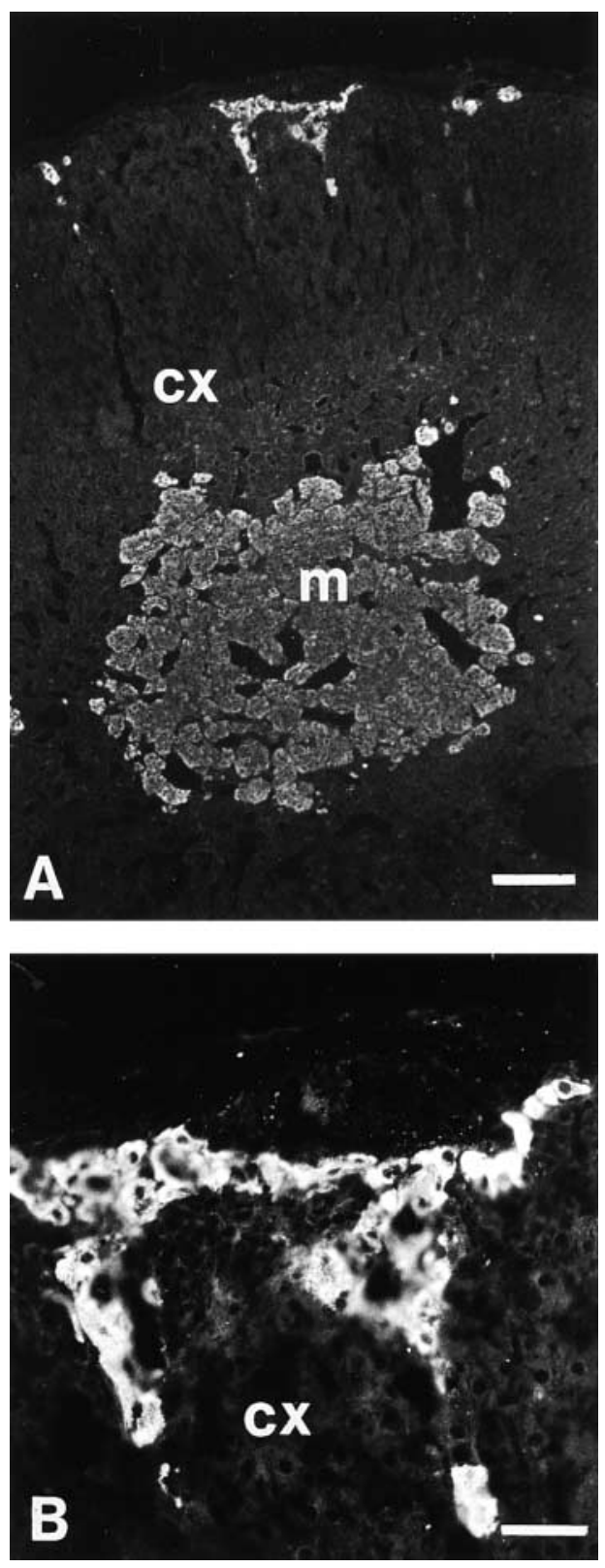

Figure 9 Photomicrographs showing the distribution of EM66-like immunoreactivity in the rat adrenal gland. (A) Intense immunofluorescence labeling was observed in chromaffin cells in the medulla (m). (B) Rays of EM66-IR chromaffin cells were also observed in the cortex $(c x)$, whereas adrenocortical cells were devoid of labeling. Bars: $\mathbf{A}=100 \mu \mathrm{m} ; \mathbf{B}=50 \mu \mathrm{m}$.

ing that EM66 is present only in adrenergic cells and not in noradrenergic cells of the rat adrenal gland.

Immunocytochemical labeling of chromaffin cells showed that EM66-IR was restricted to secretory granules (Figures 11A and 11B). In contrast, adrenocortical cells did not exhibit any staining (Figure 11A). When the antiserum was absorbed with the antigen, no association of gold particles with any cell types in the adrenal gland could be observed (data not shown).

\section{Discussion}

The present study has demonstrated the occurrence of a novel SgII-derived peptide, EM66, in the rat pituitary and adrenal, and has described its cellular and subcellular distribution in these endocrine glands.

Several lines of evidence indicate that SgII is a precursor protein that gives rise to biologically active peptides. (a) SgII contains pairs of basic amino acids that are known to be privileged targets of PCs in endocrine and neuroendocrine cells (Gerdes et al. 1988; Fischer-Colbrie et al. 1990; Anouar et al. 1996). (b) SgII is cleaved by the convertases PC1 and PC2 (Tooze et al. 1994; Laslop et al. 1998). (c) A post-translational processing product of SgII, the peptide SN, has been identified in the brain of frog and mammals (Vaudry and Conlon 1991; Marksteiner et al. 1993). (d) SN is released from endocrine and nerve cells upon stimulation (Kirchmair et al. 1994; Turquier et al. 2001). We have previously shown that SgII, in addition to SN, can give rise to the peptide EM66 in human adrenal gland (Anouar et al. 1998). Because the sequence of EM66 is highly conserved among species (Anouar et al. 1996), we postulated that the antisera directed against the human peptide may allow more precise characterization of the occurrence and distribution of EM66 in different endocrine tissues of rat. Analysis of tissue extracts by reversed-phase HPLC combined with RIA has revealed that EM66 is formed in the rat pituitary and adrenal, indicating that this SgII-derived peptide can be generated in various tissues and in different species. In the anterior pituitary, a second peak of EM66-IR material was also resolved. Owing to its higher retention time, this peak may correspond to an intermediate processing product of SgII, i.e., a C- and/or N-extended form of EM66.

In the anterior pituitary, intense EM66-IR was observed in all gonadotrophs as revealed by double labeling using a monoclonal antibody against $\mathrm{LH} \beta$. This finding is consistent with previous reports showing that $\mathrm{SgII}$ is a major product of gonadotrophs, in which its biosynthesis and release are regulated by gonadotropin-releasing hormone and sex steroids (Chanat et al. 1988; Anouar et al. 1991; Anouar and Duval 1992; Lloyd et al. 1992; Fischer-Colbrie et al. 1995; Watanabe et al. 1998). The intense EM66-IR observed in all gonadotrophs suggests that this peptide may represent a sensitive circulating marker for the diagnosis of human gonadotrope adenomas. In particular, EM66 may represent a valuable tool to characterize non-functioning pituitary tumors whose secretory granules have been shown to store SgII in the absence of the resident hormones (Rosa et al. 1992; Vallet et al. 1997).

Immunofluorescence labeling and co-localization experiments revealed that EM66-IR could also be detected in few lactotrophs and thyrotrophs, but not in 

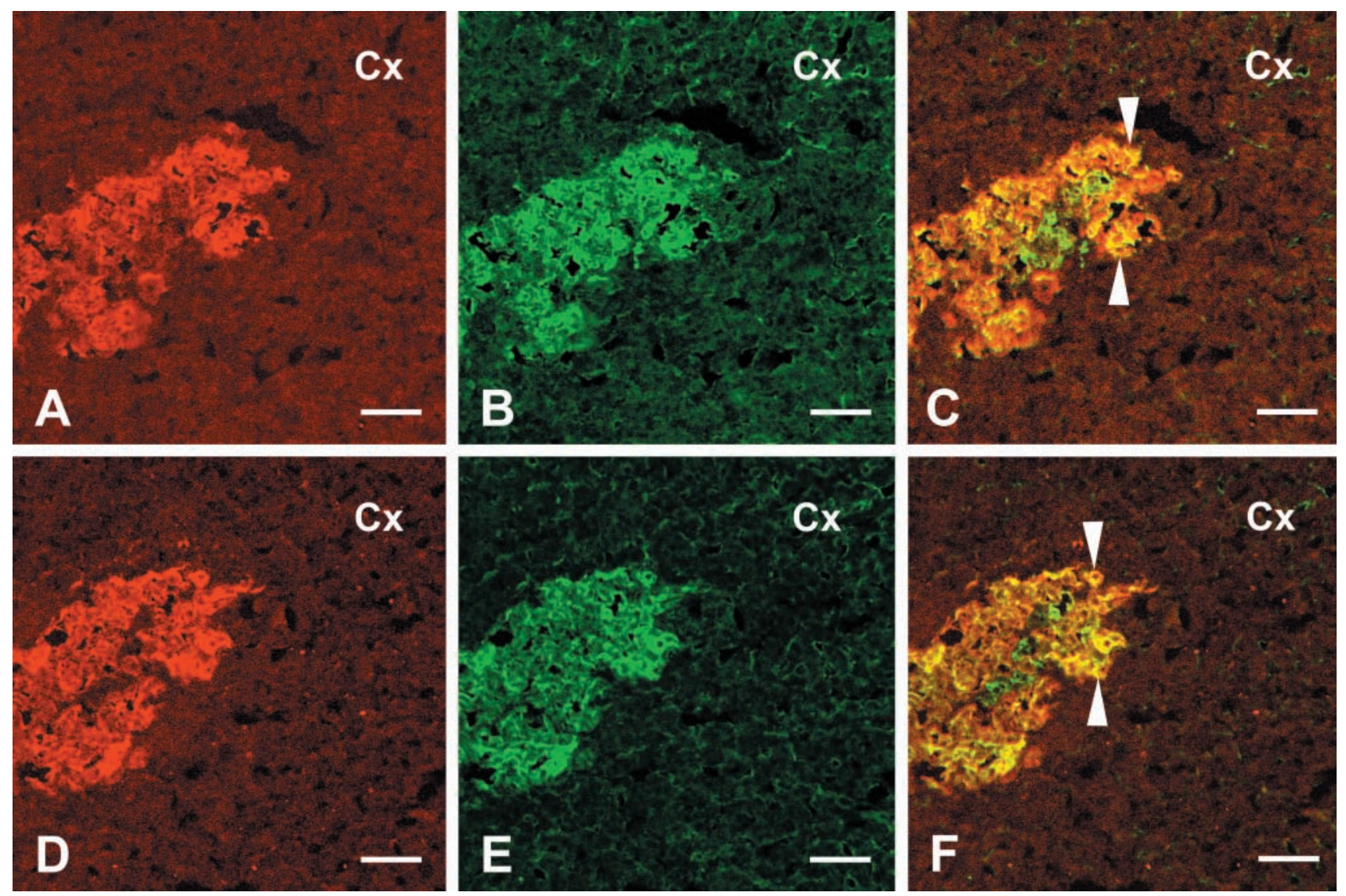

Figure 10 Confocal laser scanning microscope photomicrographs comparing the distribution of EM66, PNMT, and TH immunoreactivity in the rat adrenal gland. Sections through the adrenal were labeled with rabbit antiserum against EM66 (A) or PNMT (D) revealed with DAR/ TXR and with a monoclonal antibody against TH $(B, E)$ revealed with GAM/FITC. Combination of the two images acquired in $\mathbf{A}$ and $\mathbf{B}$, and in D and E, revealed the presence of EM66 and PNMT in the same adrenochromaffin cells, i.e., adrenergic cells (arrowheads, C and F). Bars = $100 \mu \mathrm{m}$.

corticotrophs. Given that corticotrophs have been shown to express SgII mRNA (Lloyd et al. 1992), the lack of EM66 labeling suggests that either the SgII protein is not expressed or the mature EM66 peptide is not produced in these cells, at least at detectable levels using our antibodies. In addition, electron microscopic analysis showed that somatotrophs are also devoid of EM66-IR. The differential occurrence of EM66-IR may reflect cell-specific processing of SgII that could be ascribed to the efficiency with which PCs can act on the cleavage sites of EM66 in different pituitary cells. Thus, it is now well established that both PC1 and PC2 are expressed in several cell types of the anterior pituitary, including gonadotrophs (Marcinkiewicz et al. 1993), corticotrophs (Day et al. 1992), and lactotrophs (Muller et al. 1998), and it has been shown that these processing enzymes are colocalized with chromogranins/secretogranins in pituitary and adrenal secretory granules (Scopsi et al. 1995). However, the expression level and the activity of each PC may vary depending on the cell type (Day et al.
1992; Marcinkiewicz et al. 1993), probably leading to cell-specific processing of SgII. Further studies using different cell lines transfected with SgII and PCs will be necessary to address this issue and to determine the efficiency of cleavage of EM66 from SgII. However, it should be noted that the HPLC analysis and the differential IHC localization of EM66 in the pituitary cells strongly suggest that this peptide is cleaved with a high efficiency and is the major immunoreactive SgIIderived form recognized by our antibody.

The present data also provide novel information regarding the cellular localization of a SgII-derived peptide in the rat adrenal medulla. Double labeling using antibodies against EM66, TH, and PNMT revealed that EM66-IR is restricted to a subset of TH-immunopositive cells, i.e., PNMT-expressing adrenergic cells. This finding highlights again the cell-specific occurrence of EM66 within endocrine tissues and implies either that SgII is expressed only in adrenergic cells, or that different mechanisms of SgII processing occur in adrenergic and noradrenergic chromaffin 

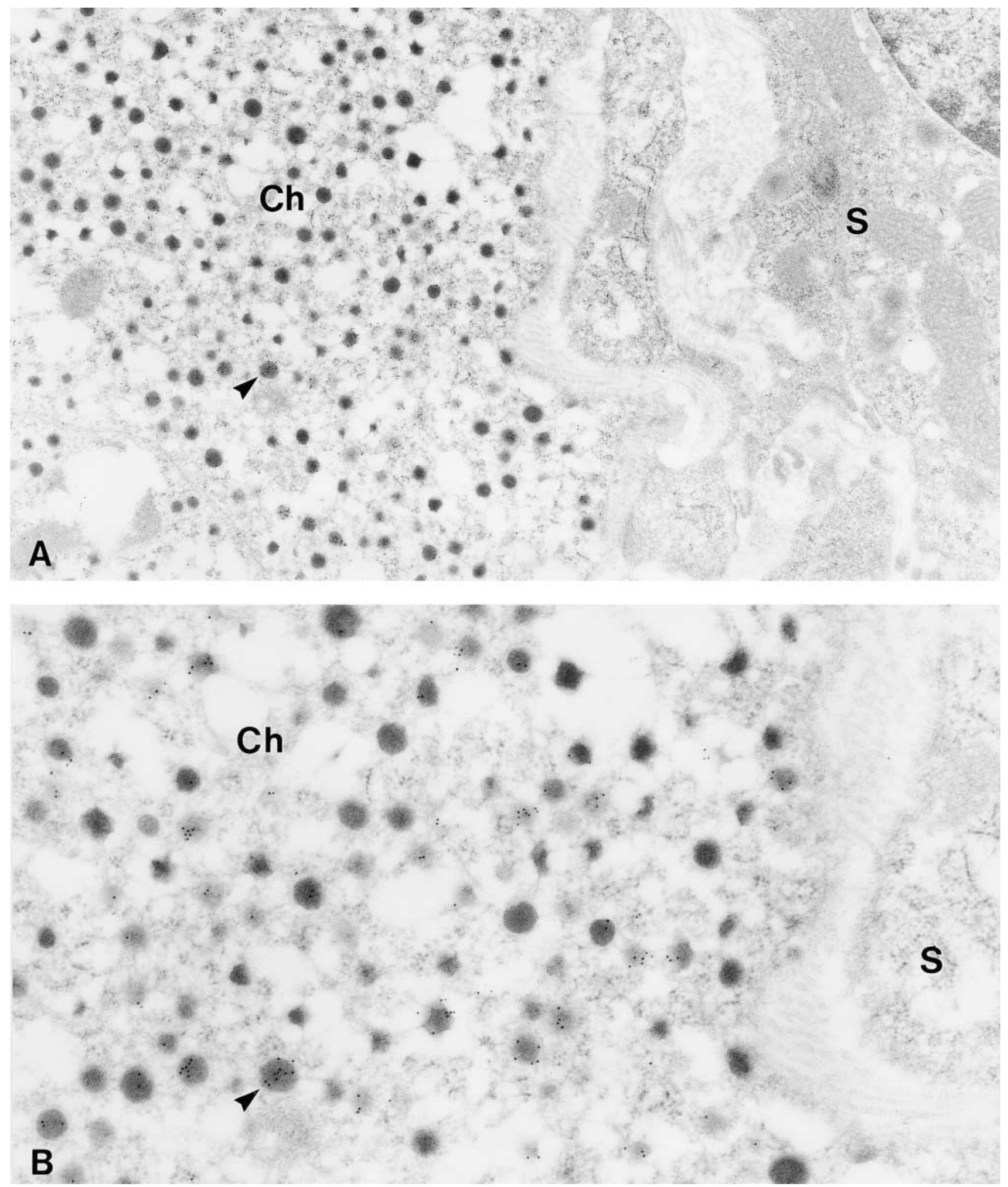

Figure 11 Immunoelectron microscopic localization of EM66 in the adrenal gland. (A) Gold particles are located over secretory granules (arrowhead) of a chromaffin cell (Ch) whereas an adjacent steroid-secreting cell (S) is unlabeled. Original magnification $\times 25,000$. (B) Higher magnification of a portion of the chromaffin cell. Original magnification $\times 50,000$. 
cells in vivo leading to production of EM66 in the former but not in the latter cells. Several studies using different experimental systems have shown that SgII can be cleaved by PC1 and PC2 in rat pheochromocytoma PC12 cells to give rise to several fragments including SN (Dittie and Tooze 1995; Hoflehner et al. 1995; Laslop et al. 1998). In addition, the presence of PC1 and PC2 has been described in chromaffin granules of the adrenal medulla (Kirchmair et al. 1993). However, it remains to be shown whether these enzymes are able to generate EM66 in chromaffin cells and whether the absence or presence of EM66-IR in chromaffin cell subpopulations is related to differential expression of PC1 and PC2 in these cells. Several reports have previously shown the existence of rays and islets of chromaffin cells in the adrenal cortex (Palacios and Lafarga 1975; Gallo-Payet et al. 1987; Bornstein et al. 1991; Perraudin et al. 1993; Berka et al. 1996). The present data indicate that these extramedullary adrenochromaffin cells also contain EM66-IR, suggesting that EM66 could play a role in the paracrine communication that occurs between chromaffin and steroidogenic cells in the adrenal gland (Bornstein and Ehrhart-Bornstein 1992; Ehrhart-Bornstein et al. 1998; Bornstein et al. 2000; Delarue et al. 2001).

Electron microscopic immunocytochemistry revealed that EM66-IR is confined to secretory vesicles of anterior pituitary and adrenomedullary chromaffin cells. Together with the HPLC data showing that mature EM66 peptide is present in the pituitary and the adrenal gland, these results imply that EM66 is formed into secretory granules. Consequently, it is conceivable that EM66 can be released into the external milieu by anterior pituitary cells and adrenomedullary cells on stimulation. This hypothesis raises the possibility that EM66 may exert hormonal activities. In fact, several observations suggest that EM66 may play endocrine functions. (a) The sequence of this peptide has been highly conserved during evolution and we have found that EM66 is actually processed in human (Anouar et al. 1998), rat (this study), and frog (Yon et al. unpublished work) endocrine glands. (b) EM66 is generated early during the ontogenesis of the fetal human adrenal gland (Anouar et al. 1998), suggesting that its formation is necessary throughout life. (c) EM66 exhibits a cell-specific occurrence in endocrine tissues, where it is confined to secretory vesicles. Therefore, EM66 may be released on stimulation of endocrine cells to act as an autocrine, paracrine, and/or endocrine factor. Alternatively, EM66 may represent a conserved structural motif allowing SgII to play an intracellular role in the morphogenesis and the function of secretory vesicles because the chromogranin/secretogranin family members are postulated to have a crucial role in these processes (Yoo et al. 2000; Kim et al. 2001). Further studies are required to test these hypotheses.
In conclusion, this study has demonstrated the occurrence of EM66, a novel peptide derived from the processing of SgII, in different cell types of the rat anterior pituitary and in adrenal chromaffin cells. In addition, the present data suggest that EM66 could be stored and released from the secretory granules of these cells and thus support the notion that EM66 may play a role in the endocrine system.

\section{Acknowledgments}

Supported by grants from the Institut National de la Santé et de la Recherche Médicale (INSERM U413) and the Conseil Régional de Haute-Normandie. We are very grateful to Dr JL Do Régo for CLSM data analysis and Ms H Lemonnier for skillful technical assistance. We thank Drs JF Roser (Davis, CA), and J Cote (Laval University, Quebec, Canada) for generously supplying the LH $\beta$ antibodies and the ACTH antiserum, respectively.

\section{Literature Cited}

Ait-Ali D, Turquier V, Alexandre D, Grumolato L, Jegou S, Vaudry H, Anouar Y (2002) Molecular characterization of frog chromogranin $B$ reveals conservation of selective sequences encoding potential novel regulatory peptides. FEBS Lett 511:127-132

Anouar Y, de Monti M, Galindo E, Benie T, Aunis D, Duval J (1991) Regulatory effects of estrogens on the pituitary content of secretogranin II and chromogranin A. J Neuroendocrinol 3:232235

Anouar Y, Desmoucelles C, Yon L, Leprince J, Breault L, GalloPayet N, Vaudry H (1998) Identification of a novel secretogranin II-derived peptide $\left(\mathrm{SgII}_{187-252}\right)$ in adult and fetal human adrenal glands using antibodies raised against the human recombinant peptide. J Clin Endocrinol Metab 83:2944-2951

Anouar Y, Duval J (1991) Differential expression of secretogranin II and chromogranin A genes in the female rat pituitary through sexual maturation and estrous cycle. Endocrinology 128:13741380

Anouar Y, Duval J (1992) Direct estradiol down-regulation of secretogranin II and chromogranin A mRNA levels in rat pituitary cells. Mol Cell Endocrinol 88:97-104

Anouar Y, Jegou S, Alexandre D, Lihrmann I, Conlon JM, Vaudry $\mathrm{H}$ (1996) Molecular cloning of frog secretogranin II reveals the occurrence of several highly conserved potential regulatory peptides. FEBS Lett 394:295-299

Berka JL, Kelly DJ, Robinson DB, Alcorn D, Marley PD, Fernley RT, Skinner SL (1996) Adrenaline cells of the rat adrenal cortex and medulla contain renin and prorenin. Mol Cell Endocrinol 119:175-184

Blazquez M, Bosma PT, Chang JP, Docherty K, Trudeau VL (1998) Gamma-aminobutyric acid up-regulates the expression of a novel secretogranin-II messenger ribonucleic acid in the goldfish pituitary. Endocrinology 139:4870-4880

Bornstein SR, Ehrhart-Bornstein M (1992) Ultrastructural evidence for a paracrine regulation of the rat adrenal cortex mediated by the local release of catecholamines from chromaffin cells. Endocrinology 131:3126-3128

Bornstein SR, Ehrhart-Bornstein M, Usadel H, Böckmann M, Scherbaum WA (1991) Morphological evidence for a close interaction of chromaffin cells with cortical cells within the adrenal gland. Cell Tissue Res 265:1-9

Bornstein SR, Tian H, Haidan A, Bottner A, Hiroi N, Eisenhofer G, McCann SM, et al. (2000) Deletion of tyrosine hydroxylase gene reveals functional interdependence of adrenocortical and chromaffin cell system in vivo. Proc Natl Acad Sci USA 97:1474214747 
Chanat E, Cozzi MG, Sion B, de Monti M, Zanini A, Duval J (1988) The gonadotrope polypeptide (GP 87) released from pituitary cells under luteinizing hormone-releasing hormone stimulation is a secretogranin II form. Biochimie 70:1361-1368

Day R, Schafer MK, Watson SJ, Chretien M, Seidah NG (1992) Distribution and regulation of the prohormone convertases PC1 and PC2 in the rat pituitary. Mol Endocrinol 6:485-497

Delarue C, Contesse V, Lenglet S, Sicard F, Perraudin V, Lefebvre H, Kodjo M, et al. (2001) Role of neurotransmitters and neuropeptides in the regulation of the adrenal cortex. Rev Endocr Metab Dis 2:253-267

Dittie AS, Tooze SA (1995) Characterization of the endopeptidase PC2 activity towards secretogranin II in stably transfected PC12 cells. Biochem J 310:777-787

Ehrhart-Bornstein M, Hinson JP, Bornstein SR, Scherbaum WA, Vinson GP (1998) Intraadrenal interactions in the regulation of adrenocortical steroidogenesis. Endocr Rev 19:101-143

Fischer-Colbrie R, Gutierrez J, Hsu CM, Iacangelo A, Eiden LE (1990) Sequence analysis, tissue distribution and regulation by cell depolarization, and second messengers of bovine secretogranin II (chromogranin C) mRNA. J Biol Chem 265:9208-9213

Fischer-Colbrie R, Laslop A, Kirchmair R (1995) Secretogranin II: molecular properties, regulation of biosynthesis and processing to the neuropeptide secretoneurin. Prog Neurobiol 46:49-70

Gallo-Payet N, Pothier P, Isler H (1987) On the presence of chromaffin cells in the adrenal cortex: their possible role in adrenocortical function. Biochem Cell Biol 65:588-592

Gerdes HH, Phillips E, Huttner WB (1988) The primary structure of rat secretogranin II deduced from a cDNA sequence. Nucleic Acids Res 16:11811

Hoflehner J, Eder U, Laslop A, Seidah NG, Fischer-Colbrie R, Winkler H (1995) Processing of secretogranin II by prohormone convertases: importance of PC1 in generation of secretoneurin. FEBS Lett 360:294-298

Holthuis JC, Martens GJ (1996) The neuroendocrine proteins secretogranin II and III are regionally conserved and coordinately expressed with proopiomelanocortin in Xenopus intermediate pituitary. J Neurochem 66:2248-2256

Iacangelo AL, Eiden LE (1995) Chromogranin A: current status as a precursor for bioactive peptides and a granulogenic/sorting factor in the regulated secretory pathway. Regul Pept 58:65-88

Jegou S, Tonon MC, Leroux P, Delarue C, Leboulenger F, Pelletier G, Cote J, et al. (1983) Immunological characterization of endorphins, adrenocorticotropin, and melanotropins in frog hypothalamus. Gen Comp Endocrinol 51:246-254

Kim T, Tao-Cheng JH, Eiden LE, Loh YP (2001) Chromogranin A, an "on/off" switch controlling dense-core secretory granule biogenesis. Cell 106:499-509

Kirchmair R, Hogue-Angeletti R, Gutierrez J, Fischer-Colbrie R, Winkler H (1993) Secretoneurin-a neuropeptide generated in brain, adrenal medulla and other endocrine tissues by proteolytic processing of secretogranin II (chromogranin C). Neuroscience 53:359-365

Kirchmair R, Marksteiner J, Troger J, Mahata SK, Mahata M, Donnerer J, Amann R, et al. (1994) Human and rat primary C-fibre afferents store and release secretoneurin, a novel neuropeptide. Eur J Neurosci 6:861-868

Kurosumi K (1968) Functional classification of cell types in the anterior pituitary gland accomplished by electron microscopy. Arch Histol J 29:329-362

Laslop A, Doblinger A, Weiss U (2000) Proteolytic processing of chromogranins. Adv Exp Med Biol 482:155-166

Laslop A, Weiss C, Savaria D, Eiter C, Tooze SA, Seidah NG, Winkler H (1998) Proteolytic processing of chromogranin B and secretogranin II by prohormone convertases. J Neurochem 70:374-383

Leitner B, Fischer-Colbrie R, Scherzer G, Winkler H (1996) Secretogranin II: relative amounts and processing to secretoneurin in various rat tissues. J Neurochem 66:1312-1317

Lloyd RV, Hawkins K, Jin L, Kulig E, Fields K (1992) Chromogra$\operatorname{nin} \mathrm{A}$, chromogranin B and secretogranin II mRNAs in the pitu- itary and adrenal glands of various mammals. Regulation of chromogranin A, chromogranin B and secretogranin II mRNA levels by estrogen. Lab Invest 67:394-404

Marcinkiewicz M, Day R, Seidah NG, Chretien M (1993) Ontogeny of the prohormone convertases PC1 and PC2 in the mouse hypophysis and their colocalization with corticotropin and alpha-melanotropin. Proc Natl Acad Sci USA 90:4922-4926

Marksteiner J, Saria A, Kirchmair R, Pycha R, Benesch H, FischerColbrie R, Haring C, et al. (1993) Distribution of secretoneurinlike immunoreactivity in comparison with substance P- and enkephalin-like immunoreactivities in various human forebrain regions. Eur J Neurosci 5:1573-1585

Martinat N, Hall E, Ravault JP, Dubois MP (1979) Purification of rat prolactin: development of an homologous radioimmunological assay and comparison with the NIAMDD system. Ann Biol Anim Biochem Biophys 19:1771-1788

Matteri RL, Roser JF, Baldwin DM, Lipovetsky V, Papkoff H (1987) Characterization of a monoclonal antibody which detects luteinizing hormone from diverse mammalian species. Domest Anim Endocrinol 4:157-165

Muller L, Picart R, Barret A, Seidah NG, Tougard C (1998) Immunocytochemical localization of the prohormone convertases PC1 and PC2 in rat prolactin cells. J Histochem Cytochem 46:101108

Palacios G, Lafarga M (1975) Chromaffin cells in the glomerular zone of adult rat adrenal cortex. Cell Tissue Res 164:275-278

Pelletier G (1984) The secretory process in the anterior hypothesis. In Cantin M, ed. Cell Biology of the Secretory Process. Basel, Karger, 196-213

Perraudin V, Delarue C, Lefebvre H, Contesse V, Kuhn JM, Vaudry H (1993) Vasopressin stimulates cortisol secretion from human adrenocortical tissue through activation of $\mathrm{V}_{1}$ receptors. $\mathrm{J}$ Clin Endocrinol Metab 76:1522-1528

Rosa P, Bassetti M, Weiss U, Huttner WB (1992) Widespread occurrence of chromogranins/secretogranins in the matrix of secretory granules of endocrinologically silent pituitary adenomas. J Histochem Cytochem 40:523-533

Rosa P, Gerdes HH (1994) The granin protein family: markers for neuroendocrine cells and tools for the diagnosis of neuroendocrine tumors. J Endocrinol Invest 17:207-225

Roth J, Bendayan M, Orci L (1978) Ultrastructural localization of intracellular antigens by the use of protein-A gold complex. J Histochem Cytochem 26:1074-1081

Scopsi L, Gullo M, Rilke F, Martin S, Steiner DF (1995) Proprotein convertases (PC1/PC3 and PC2) in normal and neoplastic human tissues: their use as markers of neuroendocrine differentiation. J Clin Endocrinol Metab 80:294-301

Simon JP, Aunis D (1989) Biochemistry of the chromogranin A protein family. Biochem J 262:1-13

Tillet Y (1988) Adrenergic neurons in sheep brain demonstrated by immunohistochemistry with antibodies to phenylethanolamine N-methyltransferase (PNMT) and dopamine-beta-hydroxylase (DBH): absence of the $\mathrm{C} 1$ cell group in the sheep brain. Neurosci Lett 95:107-112

Tooze SA, Hollinshead M, Dittie AS (1994) Antibodies to secretogranin II reveal potential processing sites. Biochimie 76:271-276

Turquier V, Vaudry H, Jegou S, Anouar Y (1999) Frog chromogranin A messenger ribonucleic acid encodes three highly conserved peptides. Coordinate regulation of proopiomelanocortin and chromogranin A gene expression in the pars intermedia of the pituitary during background color adaptation. Endocrinology 140:4104-4112

Turquier V, Vaudry H, Montero M, Yon L, Anouar Y. (2000) Characterization of chromogranins in the frog Rana ridibunda: structure, expression, and functional implications. Adv Exp Med Biol 482:125-136

Turquier V, Yon L, Grumolato L, Alexandre D, Fournier A, Vaudry H, Anouar Y (2001) Pituitary adenylate cyclase-activating polypeptide stimulates secretoneurin release and secretogranin II gene transcription in bovine adrenochromaffin cells through multiple signaling pathways and increased binding of pre-exist- 
ing activator protein-1-like transcription factors. Mol Pharmacol $60: 42-52$

Uchiyama H, Koda A, Komazaki S, Oyama M, Kikuyama S (2000) Occurrence of immunoreactive activin/inhibin beta(B) in thyrotropes and gonadotropes in the bullfrog pituitary: possible paracrine/autocrine effects of activin B on gonadotropin secretion. Gen Comp Endocrinol 118:68-76

Vallet VS, Li JY, Duval J (1997) Secretogranin II (SgII) distribution and processing studies in human normal and adenomatous anterior pituitaries using new polyclonal antibodies. Regul Pept 68:155-163

Vaudry H, Conlon JM (1991) Identification of a peptide arising from the specific post-translation processing of secretogranin II. FEBS Lett 284:31-33
Watanabe T, Banno T, Jeziorowski T, Ohsawa Y, Waguri S, Grube D, Uchiyama Y (1998) Effects of sex steroids on secretory granule formation in gonadotropes of castrated male rats with respect to granin expression. Endocrinology 139:2765-2773

Wiedermann CJ (2000) Secretoneurin: a functional neuropeptide in health and disease. Peptides 21:1289-1298

Winkler H, Fischer-Colbrie R (1992) The chromogranins A and B: the first 25 years and future perspectives. Neuroscience 49:497528

Yoo SH, So SH, Kweon HS, Lee JS, Kang MK, Jeon CJ (2000) Coupling of the inositol 1,4,5-trisphosphate receptor and chromogranins A and B in secretory granules. J Biol Chem 275:1255312559 